\title{
The Politics of Cramped Space: Dilemmas of Action, Containment and Mobility
}

\author{
William Walters ${ }^{1} \cdot$ Barbara Lüthi $^{2}$
}

Published online: 5 September 2016

(C) Springer Science+Business Media New York 2016

\begin{abstract}
This article introduces a special issue oriented to the theme of cramped space. We look to cramped space to advance critical understanding of the relationship between space, mobility and politics. Cramped space registers degrees of deprivation, constriction, and obstruction, but always and simultaneously a concern for the ways in which such limits operate to stimulate and incite movements of becoming and remaking. With this point in mind we argue that the idea of cramped space promises to foster a fruitful dialogue between two lines of research that have hitherto unfolded separately. The first of these is the recent shift within globalization theories and mobility studies away from the initial overly-optimistic focus on unbounded flows, and towards questions of friction, containment, blockage, mediation and infrastructure. The second is Deleuze and Guattari's argument for minor politics (from where the idea of cramped space originates). Addressing an age when talk of fences and walls saturates public rhetoric, the essays collected here think through cramped space to imagine new vistas of the politics of mobility.
\end{abstract}

Keywords Mobility $\cdot$ Politics $\cdot$ Borders $\cdot$ Space $\cdot$ Social theory $\cdot$ Resistance

1. X-ray images showing migrants hidden and cramped in trucks and amidst cargo might not be a staple but neither are they an uncommon feature of newspaper, TV and internet coverage of border and migration issues. Scholarly volumes too have featured such images on their covers (e.g. Tirman 2004). As such, X-ray vehicles have become one of the more potent and disturbing visual elements in today's mass-mediated 'borderscape' (Perera 2007), a space that is at once cultural, non-local and politicized. In the powerful short video Border (2001), the

William Walters

william_walters@carleton.ca

1 Department of Political Science and Department of Sociology \& Anthropology, Carleton University, Ottawa, Ontario, Canada K1S 5B6

2 Anglo-American Department of the School of History, Universität zu Köln, Albertus-Magnus-Platz, 50923 Cologne, Germany 
Belgian visual artist Hans op de Beeck unsettles the X-ray scene of clandestine migration. Border begins with the X-ray outline of eight figures. Whereas publics are now perhaps used to the static image of contained hidden bodies, Border brings this ghostly image to life. More precisely, it explores the state of containment as an uncertain border between life and death. The silhouettes are depicted moving and talking. They speak in Arabic; English subtitles reveal they are arguing about their predicament. What to do? Some express fear: will the oxygen run out? Some are reminiscing about times and places left behind. Others are dreaming of a better life. Suddenly, half way into the video, the rest of the screen illuminates and the skeletal outline of the entire truck in which the migrants are situated comes into view. We can only describe this as a moment of counter-revelation, 'counter' because now it is not the migrants who are being exposed - they were 'revealed' all along - but the technology of detection itself. What seems highly significant is that, in addition to the truck, we see at the bottom of the screen a control panel pertaining to the X-ray machine. The scopic machine that produced the X-ray is therefore brought inside the frame.

Border was shown as a video installation at various international art events. The image filled the entire wall so that the truck appeared in life size. It is a striking film for the fact that it underscores that today, borders are not only frontiers between states but a heterogeneous complex of capacities, places and authorities that bring technologies like the X-ray, the motion sensor, databases and algorithms into close and intimate contact with human bodies. One could even say that the walls of the truck come to function as a mobile and dispersed border that mobilizes not only state officials and their bureaucracies but also transportation companies and infrastructures as well. Just as the Border video has circulated in public space, so do border technologies break down human bodies - e.g. into fingerprint and iris traces - recoding them and uploading them into new circuits of capital, power and desire (Dijstelbloem and Meijer 2011; van der Ploeg 2006; Amoore 2006). As such, Border layers affective intensity around a point that geographers of borders and security have been arguing for some time: that borders do not only produce exclusion, but a kind of differentiated inclusion and that their permeability is a constitutive feature of their operation (Walters 2006; Bigo 2011; Mezzadra and Neilson 2013). Borders have become the object of a paradoxical (im) mobility, as Cunningham and Heyman argue (2004).

There is a second factor that makes this short film especially powerful. It is not merely a reflection on the securitization of borders and mobility, but the complex ways that securitization interacts with publics (Walters and D'Aoust 2015). Border speaks to and indeed harnesses the rather lurid fascination which we, as publics, have with these images and representations of borders. It draws us in but then troubles us. It troubles us not just because the scene it depicts is fraught with danger: the risks of being detected and the risks of not being detected (and here note how the almost transparent bodies hint at their vulnerability). The voices we hear transport hope and fear simultaneously - the conversation(s) 'circle around' ordinary landscapes and diminishing oxygen. The film appeals to our political emotions of uneasiness, compassion and shame. Will the travellers suffocate? How long will they survive in such 'cramped spaces'? Above all, the image troubles us because it capitalizes on our desire to watch. It is as if the inclusion of the control panel at the bottom of the screen is saying: What position do you, the viewer, occupy? Are you the border police? Are you voyeurs, perhaps consumers of suffering, subjects of a 'pornographic gaze' (Bhattacharyya 2009: 88)? What kind of world gives rise to people who travel this way? What kind of society turns such images into 'news' (Keenan 2002)? What kind of public lends it supports to the policies which produce such situations?

2. In this special issue, we call for a rethinking of the relationship between space, mobility and politics - a relationship that seems to be so central to Op de Beeck's Border, as it is to other 
initiatives in border art (for example, Alex Rivera's Borders Trilogy (2003) - see Chu, this volume). To do this, we call for further thinking about the notion of cramped space. Cramped space operates at an oblique angle towards the axes which the social sciences typically use to think about space. It is not necessarily macro or micro, global or local, public or private. Instead, it registers degrees of deprivation, constriction and obstruction, but always and simultaneously a concern for the ways in which such limits operate to stimulate and incite movements of becoming and remaking. With this point in mind, we argue that the idea of cramped space promises to foster a fruitful dialogue between two lines of research that have hitherto unfolded separately.

The first of these has to do with the theme of space and movement. Whereas earlier studies of globalization portrayed a world of unbounded movement, flows and dizzying mobility, more recent scholarship has urged caution. The metaphors of fluidity, flows, networks, disjuncture, creolization and so forth tend to neglect (and sometimes even depoliticize) the ways in which social inequality is systematically produced and maintained in a (global) space of flows (Cunningham and Heyman 2004). Newer scholarship has stressed friction (Tsing 2005), enclosure (Cunningham and Heyman 2004), and break down, immobility or stillness (Neilson and Rossiter 2011). In place of the singular emphasis of acceleration (e.g. Virilio 1986), we are learning about diverse modalities, relationships and indeed a rich multiplicity of time-spaces (May and Thrift 2001). In keeping with these themes of limits and unevenness, research on mobility is also beginning to emphasize and explore situations of constrained mobility (Uteng 2009; Bissell 2016), contained mobility (Biemann 2004), desperate mobility (Martin 2012), insurgent mobility (Nyers and Rygiel 2012) and the multiplication of borders. And theories which previously stressed the power of networks to connect and produce agency are now clarifying that the world is not made of networks alone (Latour 2011), so that our ontologies of power must be expanded to include various atmospheres, enclosures, envelopes, bubbles and other forms that contain, insulate, nurture and protect mobile life (Sloterdijk 2016).

At the same time, and in a similar vein, debates around the 'new mobilities paradigm' (Sheller and Urry 2006; Adey 2006; Adey 2010; Cresswell 2001; Cresswell 2010; Revill 2011) are moving towards a greater concern with mediations, infrastructures and moorings. Since ships need ports, buses need bus stations, human beings need spaces of rest, it is increasingly clear that such spaces have become paramount in directing or limiting mobility. As Tim Cresswell and Peter Merriman argue, these spaces 'produce structural or infrastructural contexts for the practising of mobility' and are "agents in the production of moving" (Cresswell and Merriman 2011: 7). But far from being simply contexts, spaces are also actively produced by the act of moving. Places and landscapes are 'continually practised and performed through a movement and enfolding of a myriad of people and things.' (ibid.). Places and landscapes are not just 'settings'; through the ongoing process of 'spacing' and 'placing', the world is constantly shaped and formed. Yet, 'spacing' and 'placing' can be thought of in different manners, not just as an active and unhindered process but also in terms of impediment, obstruction or 'cramping'.

While we share the concern of these literatures to give a more variegated account of movement and space that is sensitive to power relations, inequalities, discriminations and multiple experiences of mobility, we resist the move that merely prefixes the mobile with another qualifier, and therefore reinscribes, in however modified its form, one of contemporary society's most privileged values. To speak of cramped space is to read mobilities and globalizations against the grain. It is to mobilize an analytic that brings into view a different dimension of the past and present, to better balance between historically and empirically grounded studies of mobility. 
This leads us to the second line of research that we seek to bring into debates about mobilities, space and politics. Here, we turn to the work of (Deleuze and Guattari 1986; Deleuze and Guattari 1987) where the notion of cramped space plays a fragmentary but promising role in their rhizomatic geophilosophy (Deleuze and Guattari 1986: 17). Identifying the promise of the term, Nicholas Thoburn (2003) has developed cramped space from their argument for minor politics. If class, race, gender, nation and other positionalities have typically been the rallying cries for a politics that sought to ground radical change in appeals to the assembly and movement of a great majority, then minor politics begins with the claim that the people are missing. As Thoburn comments: 'If the people are missing, minor politics begins not in a space of self-determined subjective plenitude and autonomy, but in "cramped space" (Thoburn 2003: 18). We find ourselves in cramped space when the way ahead is traversed in all directions by blockages, boundaries and limits, be they social or material. Cramped space therefore forces its subjects to be creative and experimental, to pursue politics at the limit and fashion lives with whatever materials, languages and identities they find close at hand. No ready-made trajectories are available under cramped conditions, and non-linear mobility is part of the experience. Actions in this context are not linear and clearly determinable, but rather saturated by fleeting imponderableness and moments of uncertainty.

So, drawing our two lines together, we can speak of cramped space as an overlooked feature of spatial formations and a corrective to the images of the open, the connecting and the flowing which characterized early accounts of globalization and spatial transformation. We can also speak of cramped space in a socio-political sense as the condition that faces minor politics: how to proceed when lines of movement, lines of escape and lines of becoming appear blocked on all fronts. It should now be clear how these two lines converge in Op de Beeck's Border, and why we introduce our special issue with this event. The people are missing from Border. They are missing not just because the only actors depicted are ghostly silhouettes. The people are missing in a more profound sense because Op de Beeck engages in a critical activity without the move that grounds such criticism in an appeal to a transcendental subject. It is not as though he invokes some kind of global right to free movement or romanticizes migrants as nomadic subjects. Nor does he mobilize the trope of migrants as universal victims who demand our humanitarian salvation. Instead, Op de Beeck practices what we can only describe as a kind of immanent criticism. It is effective as an aesthetic intervention because of its proximity to the very scene of border struggles and the fact it is crafted out of repurposed operational data and surveillance technologies. Similarly, it is effective as a political move because it depicts the travellers not as heroes or victims but as very ordinary people caught up in extraordinary circumstances, unable to pass easily along legitimate social routes within a culture for political, economic or other reasons. And it is also politically effective because it calls a public into being, while strongly implying that this public does not and, indeed, cannot occupy a detached vantage point where it views the scene of migration in neutrality from the sidelines. Instead, the public is fully implicated in what is happening, and therefore a site of political and ethical responsibility. With Border, the public is called out.

3. No doubt some observers will question whether there really is anything very original about cramped space. Surely, recent social thought has long grappled with questions of confinement and power. Is this not one of the key contributions of Foucault's studies of discipline and panopticism? Is it not more recently a theme foregrounded in a different register-one of sovereign power, exceptionalism and bare life — in Agamben's paradigm of the camp? While 
we grant these figures have been enormously important for the study of mobility, space and politics, we argue that cramped space adds something else. It connects the study of mobilities and politics more thoroughly to themes of affects (Thrift 2008). Let us now develop this point.

Cramped is not a neutral or impassive word. The idea of cramped space addresses the actuation of mobility: how mobility really happens with its focus on the multi-sensorial and felt characteristics which become apparent in the cramped transport among Chinese coolies or among the impeded mobility of the Freedom Riders caught in the web of white supremacy, as Julie Chu and Barbara Lüthi show in this issue. This speaks to the importance of the emotional and affective dimensions of mobilities: affects and (collective) emotions that emerge through mobilities as well as the embodied sense of mobility (Adey 2010). One possible way of thinking about 'cramped' is by reflecting on the power of discomfort and the fact that discomfort is an overlooked but very significant and resonant affect in contemporary political life. Such 'ugly feelings' or negative affects, as literary theorist Sianne Ngai calls them, speak to the "predicaments posed by a general state of obstructed agency with respect to other human actors or to the social as such...' (Ngai 2005: 2). Like other feelings such as fear or rage, ugly feelings such as discomfort can be understood as 'dysphoric or experientially negative', in the sense that they evoke displeasure or pain. Ngai also describes them as " "semantically" negative, in the sense that they are saturated with socially stigmatizing meanings and values (...); and as "syntactically" negative, in the sense that they are organized by trajectories of repulsion rather than attraction' (Ngai 2005: 11). The affect we call 'discomfort' transcends scenes and images reaching from the cramped abhorrence of the transatlantic slave ship in the past to the 'floating coffins' representing the present-day refugee dilemma in many parts of the world. This affect also, for example, shows us how such disturbingly enduring representations of the Chinese as a 'distinctive race of insensible bodies inured to their own physical discomforts as well as to the suffering of others' (Chu in this issue) linger on into present-day images of 'human cargo' as Hans op de Beeck video installation Border shows. As Julie Chu argues, comfort being a relatively modern bourgeois concept of self-fashioning and rights-claiming is not just a matter of material satisfaction and technical utility, it is also aesthetic and affective as a symbol of the good life capable of moving people to help themselves and to help or impede others. Discomfort therefore speaks to the opposite of comfort: the negativity at stake is also operational, involving processes of aversion, exclusion and of course the negation of a 'good life' (Ngai 2005, p. 11f).

By drawing attention to the multiple senses and experiences of discomfort, but also of pain and other sensibilities and affects, we offer a new angle on political struggles in the past and present by thinking beyond the divisions of private and political, intimate and social. Additionally to understanding cramped spaces as a way that minorities experience the interplay between the individual and the social, the personal and the political or rather 'how the minority experience is characterized by the breakdown of these boundaries', as Thoburn argues, one must specifically take into account these affective dimensions. This does not mean just sketching out what makes 'man a political being in his faculty of action', as Hannah Arendt (1969: 31) put it, nor just denying his agency. Rather it means paying attention to the feelings that can facilitate action, provocation and critique.

4. Our goal in the special issue is to further develop the theme of cramped space. This is not because, as certain prominent thinkers of globalization have argued, we are living in an age of time-space compression (Giddens 1990; Harvey 1989) - as though we are all cramped now. Nor is it because we have in mind some kind of general history of cramped space. Doubtless, it would be interesting to consider the different ways in which cramped space has been an 
instrument or effect of domination, just as we might wonder about the different ways subjects create and endure cramped space as a mode of resistance. From priest holes to hidden compartments in trucks, and from closets to hideouts in forests near the border, the long, torturous and frequently subterranean history of cramped space as evasion remains to be written. But such an ambitious undertaking is not our task here. Rather, if we pursue this idea here, it is because the theme of cramped space within the context of mobility, space and politics promises three specific benefits.

The first reason we seek to develop this idea is related to what we might call the question of expressing and registering agency under unpromising and ambiguous conditions. The analysis of cramped experience, as Thoburn (2003: 19) argues, draws thought and practice 'back into a milieu of contestation, debate, and engagement, and forces ever new forms of experimentation' and creative social solutions. This remains a treacherous domain. Let us return to the scene which Op de Beeck tackles. There are many risks here. One risk is to project a full agency or identity onto subjects, thereby conscripting them into a cause - for example, as agents of resistance, citizenship and insurgency. Another risk is of buying into a naive liberal politics of exposure: the belief that exposing scenes of violence and domination to a public will generate movements of reform, when on the contrary such exposure may only serve to fuel the border spectacle (De Genova 2013) as its unwitting accomplice. Then, there is the risk of denying agency, and seeing only victims. Or the risk of fetishizing what is one highly visible moment in a complex migratory process, generalizing from it: as though a whole people could be defined at the level of this moment of capture - e.g. as stowaways or boatpeople (Walters 2015) - and as if there were no simultaneous, ambivalent developments. In all these moves, ambiguous affective dimensions are involved, ranging from an affirmation of life under the most cramped and seemingly impossible conditions to desolation to feelings of discomfort as a cathartic feeling that to a certain degree facilitates action, or at least provocation and critique. The power of Border is that it finds in the Xrays of the migrants a way to navigate around these perils of unambiguous representation. Formulated in proximity to the theme of minor politics, attuned to the ways in which confined circumstances can yield political creativity, the promise of cramped space is to open our eyes to the many inventive ways that actors have sought to negotiate and work through this problematic milieu.

The second benefit of cramped space is more a matter of empirical and methodological orientation. As Thoburn has clarified, Deleuze and Guattari do not make this concept a synonym for situations of physical cramping and spatial confinement. Cramped space in their work refers to social situations where relations are saturated and passages blocked. You can inhabit the vastest territory and still be cramped. It all depends. Nevertheless, and at the risk of vulgarizing this promising notion, we do suggest that places, experiences and infrastructures of contentious and contested mobility provide scholars with 'extreme cases' (Flyvbjerg, 2001) of cramped space, that is, contexts where features are pronounced and thus particularly accessible to critical thought. If cramped space occurs in situations where the way ahead appears blocked, yet where there is no option but to carry on-where Beckett's formula 'I can't go on; I'll go on' undoubtedly applies (see Thoburn, this volume)- then we intuit that one context in which these situations will occur with a heightened incidence and intensity is in today's migration world. When subjects are stuck in transit, or deprived of rights, held in detention, forced into deportation, we can expect conditions of cramped space to arise, which leads us back to mobility and more specifically its mediation. Granted that cramped space can materialize in all manner of situations, we nonetheless suggest a kind of elective affinity between cramped space and infrastructures of mobility. 
The final theme of cramped space which we foreground, and which all three of the following essays take up, is the theme of resistance and reversal. Despite the seemingly 'obstructed agency' of cramped spaces and the blocked ways ahead, this does not equal a condition of standstill or of 'a-social isolation', but rather one full of social relations. Minorities are not left without an agency, but rather with an 'agency of the mediator'. In cramped spaces, the question of resistance plays out through mediators which may have an enabling capacity to reverse, reroute or change cramped conditions. As Thoburn reminds us, a mediator can be 'real, imaginary, animate, or inanimate - a person, an object, plants, animals, myths, a certain discourse, an image, a refrain, or a problem' (see Thoburn, this volume). Whereas the 'mediator' figuring in Nicholas Thoburn's article is the experience of incarceration, interrogation and torture, in Julie Chu's piece, it is the feeling of discomfort and in Barbara Lüthi's the experience of segregated buses. They relate to 'truths' and established identities only insofar as they seek to reverse them and make visible situations and spaces of oppression or coercion that otherwise remain invisible. Thereby from each of these experiences arises a potential practice of hope and change.

As Percy Crowe reminded us back in 1938, movement among other things implies the 'will to move' (Crowe 1938). Movement is often seen as the result of rational choices. Yet since the upsurge of the new mobility paradigm, mobility studies have shown that there is more to movement than that. To come back to the video Border (Op de Beeck 2001) with which we began, it chronicles a cramped space with its diverse forms and degrees of obstruction and restriction, but at the same time it presses us to look at and imagine the creative moments induced by subjects on the move as well as at possible points of reversal and remaking generated by unforeseen events and moments which could not be anticipated. Non-linear mobility implied in the notion of cramped spaces is an actual part of the experience of people in everyday life and contemporary culture. In times of 'fortresses', sealed borders and fences saturating public rhetoric and visualizations of people on the move, it is time to create new vistas of the politics of mobility.

\section{References}

Adey, P. (2006). If immobility is everything then it is nothing: towards a relational politics of (im) mobilities. Mobilities, 1(1), 75-94.

Adey, P. (2010). Mobility. London: Routledge.

Amoore, L. (2006). Biometric borders: governing mobilities in the war on terror. Political Geography, 25, 336-351.

Arendt, H. (1969). On violence. New York: Harcourt Brace.

Bhattacharyya, G. (2009). Spectatorship and the war on terror: creating consensus through global audiences. Globalizations, 6(1), 77-90.

Biemann, Ursula. (2004) Contained mobility. (video installation, $20 \mathrm{~min}$ )

Bigo, D. (2011). Freedom and speed in enlarged borderzones. In V. Squire (Ed.), The contested politics of mobility: borderzones and irregularity. New York: Routledge.

Bissell, D. (2016). Micropolitics of mobility: public transport commuting and everyday encounters with forces of enablement and constraint. Annals of the American Association of Geographers, 106(2), 394-403.

Cresswell, T. (2001). The production of mobilities. New Formations, 43, 11-25.

Cresswell, T. (2010). Towards a politics of mobility. Environment and Planning D: Society and Space, 28(1), 17-31.

Cresswell, T., \& Merriman, P. (Eds.). (2011). Geographies of mobilities: practices, spaces, subjects. Farnham: Ashgate.

Crowe, P. (1938). On progress in geography. Scottish Geographical Magazine, 54/1, 1-18.

Cunningham, H., \& Heyman, J. (2004). Introduction: mobilities and enclosures at borders. Identities: Global Studies in Culture and Power, 11(3), 289-302.

De Genova, N. (2013). Spectacles of migrant "illegality": the scene of exclusion, the obscene of inclusion. Ethnic and Racial Studies, 36(7), 1180-1198. 
Deleuze, G., \& Guattari, F. (1986). Kafka: toward a minor literature. Minneapolis: University of Minnesota Press.

Deleuze, G., \& Guattari, F. (1987). A thousand plateaus: capitalism and schizophrenia. Minneapolis: University of Minnesota Press.

Dijstelbloem, H., \& Meijer, A. (Eds.). (2011). Migration and the new technological borders in Europe. New York: Palgrave Macmillan.

Flyvbjerg, B. 2001. Making Social Science Matter: Why Social Inquiry Fails and How it Can Succeed Again. Cambridge: Cambridge University Press.

Giddens, A. (1990). The consequences of modernity. Stanford: Stanford University Press.

Harvey, D. (1989). The condition of postmodernity. Oxford: Basil Blackwell.

Keenan, T. (2002). Publicity and indifference (Sarajevo on TV). PMLA, 117(1), 104-116.

Latour, B. (2011) 'Some experiments in art and politics', e-flux \#23. http://www.e-flux.com/journal/someexperiments-in-art-and-politics/

Martin, C. (2012). Desperate mobilities: logistics, security and the extra-logistical knowledge of "appropriation". Geopolitics, 17(2), 355-376.

May, J., \& Thrift, N. (Eds.). (2001). Timespace: geographies of modernity. London: Routledge.

Mezzadra, S., \& Neilson, B. (2013). Border as method; or, the multiplication of labor. Durham: Duke University Press.

Neilson, B., \& Rossiter, N. (2011). Still waiting, still moving: on labour, logistics and maritime industries. In D. Bissell \& G. Fuller (Eds.), Stillness in a mobile world. London: Routledge.

Ngai, S. (2005). Ugly feelings. Cambridge: Harvard University Press.

Nyers, P., \& Rygiel, K. (Eds.). (2012). Citizenship, migrant activism and the politics of movement. Abingdon: Routledge.

Op de Beeck, H. (2001) Border (video 3' 19"). http://www.hansopdebeeck.com/works/2001/border

Perera, S. (2007). A Pacific Zone? Security, sovereignty, and stories of the Pacific borderscape. In P.K. Rajaram and C. Grundy-Warr (eds) Borderscapes: hidden geographies and politics at territory's edge (pp. 201-227) Minneapolis; University of Minnesota Press.

Revill, G. (2011). Mobility. In J. A. Agnew \& J. S. Duncan (Eds.), The Wiley companion to human geography (pp. 373-386). Malden: Wiley-Blackwell.

Sheller, M., \& Urry, J. (2006). The new mobilities paradigm. Environment and Planning D, 38, 207-226.

Sloterdijk, P. (2016). In B. Klein (Ed.), Peter Sloterdijk: selected exaggerations: conversations and interviews 1993-2012. Malden, MA: Polity.

Thoburn, N. (2003). Deleuze, Marx and politics. London: Routledge.

Thrift, N. (2008). Non-representational theory: space, politics, affect. London: Routledge.

Tsing A, L. (2005). Friction: an ethnography of global connection. Princeton: Princeton University Press.

Uteng T, P. (2009). Gender, ethnicity, and constrained mobility: insights into the resultant social exclusion. Environment and Planning A, 41(5), 1055-1071.

van der Ploeg, I. (2006). The machine-readable body. Maastricht: Shaker.

Virilio, P. (1986). Speed and politics. New York: Semiotext(e).

Walters, W. (2006). Rethinking borders beyond the state. Comparative European Politics, 4(2/3), 141-159.

Walters, W. (2015). Migration, vehicles, and politics: three theses on viapolitics. European Journal of Social Theory, 18(4), 469-488.

Walters, W., \& D’Aoust, A.-M. (2015). Bringing publics into critical security studies: notes for a research agenda. Millennium, 44(1), 45-68. 